\title{
The use of chromic oxide as an index for determining the digestibility of feed constituents in buffalo calves
}

\author{
OM PRAKASH
}

\begin{abstract}
Six murrah buffalo calves divided into two groups were fed wheat straw and concentrates mixture along with green Lucerne. The average dry matter $(\mathrm{DM})$ intake per $100 \mathrm{~kg}$ body weight $(2.94 \pm 0.36 \mathrm{~kg})$ and g/ unit metabolic size $\left(\mathrm{g} / \mathrm{w}^{0.75}\right)(119.01$ $\pm 7.54 \mathrm{~g})$ were significantly higher $(\mathrm{P}<0.05)$ in the animals of group II than the values obtained in the group I $(2.25 \pm 0.32 \mathrm{~kg}$ and $95.79 \pm 10.03 \mathrm{~g})$. The intake of digestible crude protein (DCP) $\mathrm{g} /$ unit metabolic size was lower $(6.57 \pm 0.57 \mathrm{~g})$ in the males group than the females group $(7.06 \pm 0.71 \mathrm{~g})$ whereas, the intake of total digestible nutrients (TDN) $\mathrm{g} /$ unit metabolic size was higher in the males group $(77.79 \pm 12.27)$ than the females group $(68.02 \pm 13.38)$. The differences in the intake and utilization of these nutrients between two groups of animals were statistically significant. The average digestibility co-efficients of DM, crude protein $(\mathrm{CP})$, ether extract $(\mathrm{EE})$, crude fibre $(\mathrm{CF})$, nitrogen-free extract (NFE), total carbohydrates (TCHO), total ash, insoluble ash, neutral detergent fibre (NDF), acid detergent fibre (ADF) were 62.41 $\pm 1.13,69.57 \pm 0.89,54.13 \pm 1.81,63.50 \pm 0.86,66.74 \pm 2.79,65.61$ $\pm 3.29,35.40 \pm 2.08,54.27 \pm 1.38$ and $74.73 \pm 2.46$ per cent in the animals of group I and 58.29 $\pm 1.44,66.02 \pm 0.36,50.34 \pm 0.49,61.10$ $\pm 0.79,63.58 \pm 1.80,63.38 \pm 2.41,31.79 \pm 1.39,51.68 \pm 0.71$ and $68.64 \pm 1.97$ per cent in the animals of group II. Among the nutrients, the males digested more $(\mathrm{P}<0.05)$ crude protein than the females.
\end{abstract}

KEY WORDS : Digestibility, Chromic oxide, Buffalo, Group, Faeces

HOW TO CITE THIS PAPER : Prakash, Om (2016). The use of chromic oxide as an index for determining the digestibility of feed constituents in buffalo calves. Res. J. Animal Hus. \& Dairy Sci., 7(2) : 68-74 : DOI: 10.15740/HAS/RJAHDS/7.2/68-74.

\section{AUTHOR FOR CORRESPONDENCE}

Om Prakash, Department of Animal Husbandry and Dairying, Amar Singh (P.G.) College, Lakhaoti, BULANDSHAHR (U.P.) INDIA 